\title{
Influence of Marigold Petal Meal Rich in Xanthophyll as a Component of Commercial Layer Diets on Egg Quality Parameters
}

\author{
V. G. Navya ${ }^{1}$, B. Hemla Naik ${ }^{1}$, T. Thirumalesh ${ }^{2}$, D. Thippesh ${ }^{1}$, \\ B. U. Umesh ${ }^{2 *}$, Y. Kanthraj ${ }^{3}$ and Jyothi M. Rathod ${ }^{4}$ \\ ${ }^{1}$ Department of Horticulture, College of Agriculture, UAHS, Shivamogga-577204, \\ Karnataka, India \\ ${ }^{2}$ Department of LFC, Veterinary College, shivamogga, India \\ ${ }^{3}$ College of Horticulture, Mudigere, India \\ ${ }^{3}$ K.V.K. Shivamogga, India \\ *Corresponding author
}

\section{A B S T R A C T}

\section{Ke y w o r d s \\ Marigold petal meal, Xanthophylls, Egg yolk, Egg composition and Yolk index \\ Article Info \\ Accepted: \\ 17 August 2020 Available Online: \\ 10 September 2020}

The study was conducted to determine the effect of marigold (Tagetuserecta L.) and its petal meal on yolk colour and egg quality parameters in commercial layers. One twenty hyline birds (24weeks old) were divided into five groups of four replication each and each replication had six birds each in CDR. The marigold petal meal (MPM) was incorporated in the diet of commercial layers at 0 (T1), 3 (T2), 4 (T3), 5 (T4) and $6 \%$ (T5) levels. The $\mathrm{CP}$ content of experimental diets ranged from 16.53 to 18.82 per cent and MPM contained $12.49 \% \mathrm{CP}$ and $11.43 \% \mathrm{EE}$ and $2400 \mathrm{mg} / \mathrm{kg}$ of petal meal. No significant difference was observed in shell thickness, Haugh unit, yolk index and albumen index between the groups. Significantly higher $(\mathrm{P} \leq 0.01)$ yolk color and xanthophylls content in yolk was observed in T5 followed by T4, T3, T2 and T1. All MPM fed groups had significantly higher $(\mathrm{P} \leq 0.01) \mathrm{CP}$ level in egg and egg yolk than $\mathrm{T} 1$. But transfer of xanthophyll pigment from feed to yolk was $95.04 \%$ in T1 than other groups. It was concluded that up to $6 \%$ level of MPM inclusion in the layer diet maintained egg quality parameters as that of control group and xanthophyll content of egg yolk, yolk colour and CP content were higher as the level of MPM increased in the diet.

\section{Introduction}

In poultry industry, maize is used extensively as a source of energy and invariably it is a source of xanthophylls also. However, due to rise in the cost of maize recently, search for alternate source of feed resources either as source of pigment or any other nutrients is a major thrust area in the field of poultry nutrition. Marigold petal meal is one among several unconventional feed stuffs available locally to the farmers where it contained 11 to 12 per cent crude protein (CP) and 10-11 per cent EE (Sujatha et al., 2015). In addition, it has 100 times more xanthophylls than maize. Most of the findings are based on the extract from marigold flower inclusion in the diets of layers, but very little information is available on direct feeding of marigold as feed additive at very lower levels. Information on higher 
level of inclusion as source of unconventional feed ingredient to replace some of the milling by-products partially or completely to reduce the cost of production is scarce. Therefore, this study was taken up to know the use of marigold petal meal as a component of layer diet by replacing some of the conventional feed ingredients on egg quality parameters, yolk color and xanthophylls content of egg yolk in commercial layers.

\section{Materials and Methods}

One hundred twenty, twenty-four weeks old White Leghorn pullets of Hyline strain were divided in to five groups of four replication each and six birds in each replication in complete randomized design. The birds were maintained under standard management protocol at Poultry Experimental Unit, Dept. of Livestock Farm complex, Veterinary College, Shivamogga. The approval of institutional ethical committee for the experiment was obtained with the guidelines laid down by the Institute of Animal Ethics Committee for the use of Poultry birds.

Marigold flowers (Tagetes erectus L.) were grown at farm section of Dept. of Horticulture, College of Agriculture, Shivamogga. The marigold petals were separated from calyx and seeds and shade dried till the moisture level reduced from 92 to 0 per cent. The dried marigold petals were ground to pass through $1 \mathrm{~mm}$ sieve and incorporated at 0 (T1), 3 (T2), 4 (T3), 5 (T4), $6 \%$ (T5) levels in in the standard layer diet (SLD) formulated as per BIS (2007) specification for layers. The SLD contained crude protein 17 per cent, Metabolizable Energy $2600 \mathrm{kcal} / \mathrm{kg}$ diet, calcium 3.6 per cent, phosphorus 0.736 per cent and available phosphorus 0.36 per cent. The experiment was started when layers were $24^{\text {th }}$ weeks of age and the laying phase was divided in to three periods of four weeks each from $24^{\text {th }}$ to $35^{\text {th }}$ weeks (Period $-\mathrm{I} 24^{\text {th }}$ to $27^{\text {th }}$, Period-2 $28^{\text {th }}$ to $31^{\text {st }}, \quad$ Period- $32^{\text {nd }}$ to $35^{\text {th }}$ ). The experiment was conducted for a period of 120 days. During the experiment, egg quality parameters like shell thickness, Haugh units, yolk index, albumen index, yolk color were estimated. The xanthophylls in yolk and proximate composition of egg without shell and yolk were estimated. The samples of feed, maize and marigold petal meal were collected and subjected for chemical composition (AOAC, 2016) and xanthophylls content of maize, MPM and yolk was analyzed (AOAC, 2016). The data collected was analysed statistically (SPSS, $15^{\text {th }}$ version, 2017).

\section{Results and Discussion}

The ingredient composition of treatment diets are given in Table 1. The inclusion level of maize in all the treatment diets was kept constant $(55 \%)$ to know changes in egg color and xanthophylls content and transfer from the feed to yolk when compared to marigold petal meal (MPM) incorporated diets. The MPM was incorporated at different levels in the layers' diet by replacing deoiled rice bran and sunflower meal partially but the level of nutrients kept constant in all the diets according to BIS (2007) specifications so that all the diets should contain 18 per cent crude protein (CP) and $2700 \mathrm{Kcal} / \mathrm{kg}$ of metabolic energy (ME). However, the CP content of experimental diets ranged from 16.53 to 18.82 per cent, and crude fibre $(\mathrm{CF})$ ranged from 7.69 to 9.69 per cent, calcium $(\mathrm{Ca})$ ranged from 4.87 to 6.1 per cent, and phosphorus (P) ranged from 0.89 to 2.28 per cent (Table 2). However, all the nutrient levels in all treatment groups were well above the recommended level of BIS (2007) specifications. These specifications were similar to the specifications maintained in the diet of commercial layers prepared by the various researchers (Hasin et al., 2006; Moeini et al., 2012; Sujatha et al., 2015). 
Table.1 Ingredient composition (\% as is basis) of experimental diets of commercial layers

\begin{tabular}{|c|c|c|c|c|c|}
\hline Ingredient & $\mathbf{T}_{1}$ & $\mathbf{T}_{2}$ & $\mathbf{T}_{\mathbf{3}}$ & $\mathbf{T}_{4}$ & $\mathbf{T}_{5}$ \\
\hline Marigold petal meal MPM) & 0 & 3 & 4 & 5 & 6 \\
\hline Maize & 55 & 55 & 55 & 55 & 55 \\
\hline Deoiled rice bran & 7 & 5.5 & 4 & 3.5 & 2.5 \\
\hline Sunflower meal & 6 & 3 & 3 & 2 & 2 \\
\hline Soybean meal & 21 & 22 & 22 & 22.5 & 23 \\
\hline Limestone powder & 2 & 2 & 2 & 2 & 2 \\
\hline Shell Grit & 7 & 7 & 7 & 7 & 7 \\
\hline Dicalcium phosphate & 1.2 & 1.2 & 1.2 & 1.2 & 1.2 \\
\hline Salt & 0.5 & 0.5 & 0.5 & 0.5 & 0.5 \\
\hline Vegetable oil & 0 & 0.5 & 1.0 & 1.0 & 1.0 \\
\hline$A B_{2} D_{3} K^{I}$ & 0.015 & 0.015 & 0.015 & 0.015 & 0.015 \\
\hline B-complex ${ }^{2}$ & 0.02 & 0.02 & 0.02 & 0.02 & 0.02 \\
\hline Trace minerals ${ }^{3}$ & 0.1 & 0.1 & 0.1 & 0.1 & 0.1 \\
\hline Lysine & 0.1 & 0.1 & 0.1 & 0.1 & 0.1 \\
\hline Methionine & 0.1 & 0.1 & 0.1 & 0.1 & 0.1 \\
\hline Total & 100.0355 & 100.035 & 100.035 & 100.035 & 100.035 \\
\hline
\end{tabular}

Table.2 Chemical composition (\% on DMB) of commercial layer diets and marigold petal meal (MPM) used in the experiment

\begin{tabular}{|c|c|c|c|c|c|c|c|}
\hline Particular & $\begin{array}{c}\mathbf{T}_{1} \\
\text { (Control, } \\
\mathbf{0 \%})\end{array}$ & $\begin{array}{c}\mathbf{T}_{2} \\
(3 \% \\
\text { MPM) }\end{array}$ & $\begin{array}{c}\mathrm{T}_{3} \\
(4 \% \\
\mathrm{MPM})\end{array}$ & $\begin{array}{c}\mathbf{T}_{4} \\
(5 \% \\
\text { MPM) }\end{array}$ & $\begin{array}{c}\mathbf{T}_{5} \\
(6 \% \\
\text { MPM) }\end{array}$ & MPM & Maize \\
\hline Dry Matter & 93.4 & 93.63 & 94.29 & 92.95 & 92.62 & $7.76^{\phi}$ & 89.73 \\
\hline Organic Matter & 85.33 & 85.19 & 84.08 & 85.78 & 83.80 & 92.77 & 98.75 \\
\hline Crude protein & 16.58 & 18.82 & 16.94 & 16.53 & 17.86 & 12.49 & 9.17 \\
\hline Ether extract & 2.65 & 4.33 & 4.07 & 3.55 & 4.42 & 11.43 & 3.39 \\
\hline Total ash & 14.67 & 14.81 & 15.92 & 14.22 & 16.20 & 7.23 & 1.25 \\
\hline Crude fibre & 8.78 & 9.69 & 9.34 & 7.69 & 8.21 & 23.22 & 2.58 \\
\hline $\begin{array}{c}\text { Nitrogen free } \\
\text { extractives }\end{array}$ & 57.32 & 52.35 & 53.73 & 58.01 & 53.31 & 45.63 & 83.65 \\
\hline Calcium & 4.87 & 4.91 & 5.22 & 6.1 & 5.25 & 0.95 & 1.29 \\
\hline Phosphorus & 0.89 & 1.44 & 1.31 & 1.72 & 2.28 & 0.72 & 0.45 \\
\hline $\mathrm{ME}^{\#} \mathrm{kcal} / \mathrm{kg}$ & 2555 & 2546 & 2561 & 2547 & 2539 & - & - \\
\hline Xanthophylls mg/kg & - & - & - & - & - & 2400 & 21 \\
\hline
\end{tabular}

"ME - Metabolized Energy (calculated), DORB- De-oiled rice bran,

MPM- Marigold petal meal ${ }^{\phi}$ Fresh flowers 
Table.3 Effect of dietary inclusion of marigold petal meal on shell thickness (mm) and Haugh unit in commercial layers

\begin{tabular}{|c|c|c|c|c|c|c|}
\hline \multirow[t]{3}{*}{ Treatment } & \multicolumn{3}{|c|}{ Shell thickness (mm) } & \multicolumn{3}{|c|}{ Haugh unit } \\
\hline & \multicolumn{3}{|c|}{ Period } & \multicolumn{3}{|c|}{ Period } \\
\hline & I & II & III & $\mathbf{I}$ & II & III \\
\hline $\mathbf{T}_{1}$ & 0.35 & 0.34 & 0.34 & 81.87 & 88.13 & 90.40 \\
\hline $\mathbf{T}_{2}$ & 0.35 & 0.35 & 0.37 & 82.62 & 87.70 & 87.48 \\
\hline $\mathbf{T}_{3}$ & 0.35 & 0.34 & 0.35 & 86.90 & 85.83 & 92.73 \\
\hline $\mathbf{T}_{4}$ & 0.37 & 0.34 & 0.35 & 86.17 & 84.88 & 86.58 \\
\hline $\mathbf{T}_{5}$ & 0.33 & 0.32 & 0.35 & 87.37 & 88.67 & 87.93 \\
\hline S. Em \pm & 0.01 & 0.01 & 0.01 & 1.08 & 0.84 & 0.91 \\
\hline P value & 0.61 & 0.53 & 0.65 & 0.38 & 0.60 & 0.18 \\
\hline Significance & NS & NS & NS & NS & NS & NS \\
\hline
\end{tabular}

MPM- marigold petal meal; Periods: I (24-27 wks), II (28-31wks), III (32-35 wks);

T1-Control (0\%), T2-3\% MPM, T3-4\% MPM, T4-5\% MPM, T6-6\% MPM

Table.4 Effect of dietary inclusion of marigold petal meal on yolk index and Albumin index in commercial layers

\begin{tabular}{|c|c|c|c|c|c|c|}
\hline \multirow[t]{3}{*}{ Treatment } & \multicolumn{3}{|c|}{ Yolk index } & \multicolumn{3}{|c|}{ Albumin index } \\
\hline & \multicolumn{3}{|c|}{ Period } & \multicolumn{3}{|c|}{ Period } \\
\hline & I & II & III & I & II & III \\
\hline $\mathbf{T}_{1}$ & 0.49 & 0.45 & 0.43 & 0.12 & 0.13 & 0.14 \\
\hline $\mathbf{T}_{2}$ & 0.46 & 0.47 & 0.45 & 0.12 & 0.13 & 0.16 \\
\hline $\mathbf{T}_{3}$ & 0.48 & 0.47 & 0.47 & 0.12 & 0.15 & 0.15 \\
\hline $\mathbf{T}_{4}$ & 0.45 & 0.48 & 0.45 & 0.14 & 0.15 & 0.15 \\
\hline $\mathbf{T}_{5}$ & 0.45 & 0.48 & 0.45 & 0.13 & 0.14 & 0.14 \\
\hline S. Em \pm & 0.01 & 0.01 & 0.01 & 0.01 & 0.01 & 0.01 \\
\hline P value & 0.17 & 0.61 & 0.38 & 0.67 & 0.29 & 0.33 \\
\hline Significance & NS & NS & NS & NS & NS & NS \\
\hline
\end{tabular}

MPM- marigold petal meal; Periods: I (24-27 wks), II (28-31wks), III (32-35 wks);

T1-Control (0\%), T2-3\% MPM, T3-4\% MPM, T4-5\% MPM, T6-6\% MPM

Table.5 Effect of dietary inclusion of marigold petal meal on yolk colour and Xanthophylls content in yolk in commercial layers

\begin{tabular}{|c|c|c|c|c|c|c|}
\hline \multirow[t]{3}{*}{ Treatment } & \multicolumn{3}{|c|}{ Yolk colour } & \multicolumn{3}{|c|}{ Xanthophylls content in yolk (mg/100g of yolk) } \\
\hline & \multicolumn{3}{|c|}{ Period } & \multicolumn{3}{|c|}{ Period } \\
\hline & $\mathbf{I}$ & II & III & $\mathbf{I}$ & II & III \\
\hline $\mathbf{T}_{1}$ & $8.25^{\mathrm{b}}$ & $9.25^{\mathrm{d}}$ & $9.25^{\mathrm{b}}$ & $1.07^{\mathrm{e}}$ & $1.16^{\mathrm{e}}$ & $1.24^{\mathrm{e}}$ \\
\hline $\mathbf{T}_{2}$ & $11.00^{\mathrm{a}}$ & $10.50^{\mathrm{c}}$ & $12.75^{\mathrm{a}}$ & $3.02^{\mathrm{d}}$ & $3.45^{\mathrm{d}}$ & $3.35^{\mathrm{d}}$ \\
\hline $\mathbf{T}_{3}$ & $11.50^{\mathrm{a}}$ & $11.50^{\mathrm{bc}}$ & $13.50^{\mathrm{a}}$ & $5.44^{\mathrm{c}}$ & $5.14^{\mathrm{c}}$ & $5.48^{\mathrm{c}}$ \\
\hline $\mathbf{T}_{4}$ & $11.50^{\mathrm{a}}$ & $12.25^{\mathrm{b}}$ & $13.75^{\mathrm{a}}$ & $9.34^{\mathrm{b}}$ & $9.04^{b}$ & $9.03^{b}$ \\
\hline $\mathrm{T}_{5}$ & $11.25^{\mathrm{a}}$ & $14.00^{\mathrm{a}}$ & $14.00^{\mathrm{a}}$ & $12.69^{\mathrm{a}}$ & $12.94^{\mathrm{a}}$ & $12.87^{\mathrm{a}}$ \\
\hline S. Em \pm & 0.30 & 0.39 & 0.48 & 0.37 & 0.97 & 0.85 \\
\hline P value & 0.01 & 0.01 & 0.01 & 0.01 & 0.01 & 0.01 \\
\hline Significance & $* *$ & $* *$ & $* *$ & $* *$ & $* *$ & $* *$ \\
\hline
\end{tabular}

** $\mathrm{P} \leq 0.01$, Means bearing different superscript differ significantly between the rows. MPM- marigold petal meal

MPM- marigold petal meal; Periods: I (24-27 wks), II (28-31wks), III (32-35 wks);

T1-Control (0\%), T2-3\% MPM, T3-4\% MPM, T4-5\% MPM, T6-6\% MPM 
Table.6 Proximate composition (\% as is basis) of egg (without shell) of experimental birds

\begin{tabular}{|c|c|c|c|c|c|c|c|c|}
\hline Particular & Treatment & DM & OM & $\mathbf{C P}$ & EE & $\mathbf{T A}$ & $\mathbf{C a}$ & $\mathbf{P}$ \\
\hline \multirow{8}{*}{$\begin{array}{c}\text { Egg } \\
\text { without } \\
\text { shell }(\mathbf{1 0 0 g})\end{array}$} & $\mathrm{T}_{1}$ & 25.34 & $97.71^{\mathrm{ab}}$ & $10.47^{\mathrm{b}}$ & 7.89 & $2.30^{\mathrm{ab}}$ & 0.68 & 0.32 \\
\hline & $\mathrm{T}_{2}$ & 25.05 & $97.12^{b}$ & $11.10^{\mathrm{ab}}$ & 8.60 & $2.88^{\mathrm{a}}$ & 0.76 & 0.29 \\
\hline & $\mathrm{T}_{3}$ & 24.59 & $98.47^{\mathrm{a}}$ & $11.42^{\mathrm{a}}$ & 8.67 & $1.53^{b}$ & 0.83 & 0.30 \\
\hline & $\mathrm{T}_{4}$ & 26.54 & $98.45^{\mathrm{a}}$ & $11.84^{\mathrm{a}}$ & 9.11 & $1.55^{b}$ & 0.75 & 0.33 \\
\hline & $\mathrm{T}_{5}$ & 26.10 & $98.23^{\mathrm{a}}$ & $11.85^{\mathrm{a}}$ & 9.27 & $1.78^{b}$ & 0.91 & 0.38 \\
\hline & S. Em \pm & 0.42 & 0.16 & 0.15 & 0.17 & 0.16 & 0.05 & 0.03 \\
\hline & P value & 0.64 & 0.01 & 0.01 & 0.05 & 0.01 & 0.61 & 0.86 \\
\hline & Significance & NS & $* *$ & $* *$ & NS & $* *$ & NS & NS \\
\hline \multirow{8}{*}{$\begin{array}{c}\text { Egg yolk } \\
(\%)\end{array}$} & $\mathrm{T}_{1}$ & 56.38 & 95.92 & $14.09^{b}$ & 27.61 & 4.08 & 1.43 & 0.49 \\
\hline & $\mathrm{T}_{2}$ & 50.62 & 96.32 & $15.58^{\mathrm{a}}$ & 28.51 & 3.68 & 1.52 & 0.67 \\
\hline & $\mathrm{T}_{3}$ & 52.50 & 96.52 & $15.70^{\mathrm{a}}$ & 29.64 & 3.48 & 1.38 & 0.75 \\
\hline & $\mathrm{T}_{4}$ & 50.76 & 95.74 & $16.07^{\mathrm{a}}$ & 27.62 & 4.26 & 1.43 & 0.86 \\
\hline & $\mathrm{T}_{5}$ & 53.84 & 95.20 & $15.97^{\mathrm{a}}$ & 30.03 & 4.80 & 1.64 & 0.53 \\
\hline & S. Em \pm & 0.80 & 0.24 & 0.23 & 0.38 & 0.24 & 0.14 & 0.09 \\
\hline & P value & 0.12 & 0.48 & 0.02 & 0.12 & 0.48 & 0.99 & 0.69 \\
\hline & Significance & NS & NS & $*$ & NS & NS & NS & NS \\
\hline \multirow{8}{*}{$\begin{array}{c}\text { Egg } \\
\text { without } \\
\text { shell (60g) }\end{array}$} & $\mathrm{T}_{1}$ & 14.70 & $98.70^{\mathrm{ab}}$ & $6.36^{c}$ & 4.69 & $1.30^{\mathrm{ab}}$ & 0.39 & 0.19 \\
\hline & $\mathrm{T}_{2}$ & 15.03 & $98.34^{\mathrm{b}}$ & $6.65^{b c}$ & 5.28 & $1.67^{\mathrm{a}}$ & 0.47 & 0.17 \\
\hline & $\mathrm{T}_{3}$ & 14.74 & $99.09^{\mathrm{a}}$ & $6.71^{\mathrm{abc}}$ & 5.09 & $0.91^{b}$ & 0.48 & 0.19 \\
\hline & $\mathrm{T}_{4}$ & 15.92 & $99.06^{\mathrm{a}}$ & $7.22^{\mathrm{a}}$ & 5.41 & $0.94^{b}$ & 0.52 & 0.22 \\
\hline & $\mathrm{T}_{5}$ & 15.66 & $98.74^{\mathrm{ab}}$ & $7.08^{\mathrm{ab}}$ & 5.52 & $1.27^{\mathrm{ab}}$ & 0.65 & 0.23 \\
\hline & S. Em \pm & 0.27 & 0.09 & 0.10 & 0.11 & 0.09 & 0.04 & 0.02 \\
\hline & P value & 0.53 & 0.023 & 0.021 & 0.085 & 0.023 & 0.18 & 0.809 \\
\hline & Significance & NS & $*$ & $*$ & NS & $*$ & NS & NS \\
\hline
\end{tabular}

Marigold petal meal (MPM) contained 12.49 per cent $\mathrm{CP}, 11.43$ per cent ether extract (EE), 45.63 per cent nitrogen free extractives (NFE), 0.9 per cent calcium $(\mathrm{Ca}), 0.72$ per cent phosphorous (P) (Table 2). The $\mathrm{CP}$ content of MPM was almost similar to the milling by products like de-oiled rice bran, wheat bran and any gram husk but MPM had higher level of EE (11.43 \%). The xanthophyll content of maize grain and MPM used to prepare the experimental diets was 21 and $2400 \mathrm{mg} / \mathrm{kg}$, respectively.

There was no significant effect on shell thickness of the eggs produced by birds fed with different levels of MPM. Even though there was a variation in the calcium level among the diets (Table 2) which might be due to efficiency of utilization of calcium in formation of egg shell was similar in all groups. The levels of MPM even up to $6 \%$ in the diet of layer had not affected the calcium utilization. Therefore, shell thickness was also not differed between the groups as it mainly depends on calcium level in the diet and its utilization. Similar shell thickness values $(0.33-0.40 \mathrm{~mm})$ were reported in several studies in layers of irrespective breeds fed with various levels of either marigold petal powder or extract from marigold flowers 
(Hasin et al., 2006; Ariana et al.,2011; Sujatha et al., 2015; Rezaei et al., 2018). Themean haugh units recorded in control and treatment groups in this experiment for commercial layers were not differed significantly. MPM inclusion on haugh units was on par with the maize included diet $\left(T_{1}\right)$. Whereas the haugh unit recorded in this experiment were higher (85.93 to 88.48 ) than the values reported by Hasin et al., (2006) in marigold petal powder at 4 per cent level in Shaver 579 laying pullets (80), in hyline W 36 white hens fed with 1.5 per cent marigold powder (72.26) and in hyline (W-36) birds fed with 1 and 3 per cent marigold flower powder (Moeini et al., 2012). However, desi chicken Nicoberi fowl produced egg with higher haugh units (101) when they were fed 1 to $3 \mathrm{~g}$ marigold petal powder daily (Sujatha et al., 2015) (Table 3).

There was no significant difference in yolk index of the eggs between the treatment groups (Table 4) during the experimental period. MPM inclusion did not bring any significant change in the yolk index when compared to the maize included group $\left(\mathrm{T}_{1}\right)$. The values reported in this study $(0.46-0.47)$ were similar to the values $(0.45-0.47)$ reported in desi chicken eggs (Sujatha et al., 2015) whereas lower than the values (40-41) reported for hyline -5 laying hens (Altunta and Aydin,2014). Even though, significantly not much variation was noticed in albumin index of the eggs between the treatments (Table 4), in all MPM fed groups, similar values $(0.14)$ were obtained but higher by 1 unit than in $\mathrm{T}_{1}$ group (0.13). Much lower values of albumin index (0.07-0.09) were reported by Altunta and Aydin. (2014) and Sujatha et al., (2015).

The yolk color of the egg depends on the carotenoids or any pigments present in the feed ingredients use to prepare layers diet. At the beginning of the laying period (Period-I), irrespective of the level of MPM inclusion, birds in all treatment groups imparted same extent of colour but significantly higher than control $\left(\mathrm{T}_{1}\right)$ because birds need some time to stabilize the metabolism of carotenoids in the body. But significantly $(\mathrm{P} \leq 0.01)$ higher colour in higher level of MPM inclusion was observed $\left(\mathrm{T}_{5}\right)$ followed by lower levels of inclusion but significantly higher than $T_{1}$ (control) in period-II. Subsequently, in period-III, the level of colour was stabilized among the groups of birds that fed with various level of MPM than control $\left(\mathrm{T}_{1}\right)$. However, as the level of MPM increased in the diet, the extent of colour also increased in yolk. The yolk colour obtained in this study was higher than the values reported by Hasin et al., (2006) at 4 per cent level of marigold petal powder (8.2) and orange skin powder (3.3). Rowghwani et al., (2006) also reported lower values in marigold petal powder (8.0 to 9.0), safflower petal meal (5-6) and red pepper meal (9.5-12.5). Moeini et al., (2012) noticed higher yolk colour (13.33) in the birds fed with $3 \%$ red pepper meal in the diet of layers (Hyline W 36) which matched with 6per cent level of MPM inclusion in this study (Table 5) Oliveria et al., (2017) noticed significantly higher yolk colour (14.25) in paprika extract fed at $6 \mathrm{~g} / \mathrm{kg}$ diet in Hyline $\mathrm{W}$ 36 layer than $1 \mathrm{~g}$ marigold extract per $\mathrm{kg}$ of diet. The commercial synthetic pigment, red canthaxanthin fed at $25 \mathrm{ppm}$ to the basal diet in Hyline W-36 layers produced yolk colour that was similar to control $\left(\mathrm{T}_{1}\right)$ group of the present study (Rezaei et al., 2018).

Xanthophyll content of egg yolk estimated in all the periods was statically significant $(\mathrm{P} \leq 0.01)$ between the treatment groups. In all the periods, xanthophyll content was significantly higher in $\mathrm{T}_{5}$ followed by $\mathrm{T}_{4}, \mathrm{~T}_{3}$, $\mathrm{T}_{2}$ and $\mathrm{T}_{1}$. As the level of MPM increased in the diet of $T_{2}$ to $T_{5}$ groups, the xanthophyll content also increased according to the MPM level in the diet. The xanthophyll content of 
MPM used in the experiment is $2400 \mathrm{mg} / \mathrm{kg}$ of dried MP and intake of xanthophyll through the MPM was also increased according to the level of inclusion. However, the transfer of xanthophyll pigment from the feed to the yolk was significantly higher in groups fed with higher level of MPM ( $\left.T_{5}\right)$ then followed by $\mathrm{T}_{4}, \mathrm{~T}_{3}, \mathrm{~T}_{2}$ but transfer of xanthophyll pigment to the egg yolk was for higher than control group. When xanthophyll content of yolk is compared to the xanthophyll intake through the feed, the extent of transfer of xanthophyll from the feed to the egg yolk in T1 (maize is the only source of xanthophyll) was 95.04 per cent whereas in $\mathrm{T}_{2}, \mathrm{~T}_{3}, \mathrm{~T}_{4}$ and $\mathrm{T}_{5}$ was 37.49 , $47.60,66.84,79.49$ per cent where maize and marigold petal meal were the sources of xanthophyll. This clearly indicated that transfer of xanthophyll was more efficient in maize included diet fed group than in groups fed MPM as a supplement to maize where the efficiency was not as good as maize.

The chemical composition of egg without shell and egg yolk of eggs produced during the experiment was analysed and given in the Table 6 . The chemical composition ( $\%$ as is basis) is given both on $100 \mathrm{~g}, 60 \mathrm{~g}$ egg weight basis without shell. The CP content of an egg for $100 \mathrm{~g}$ egg was significantly $(\mathrm{P} \leq .01)$ higher in $\mathrm{T}_{3}, \mathrm{~T}_{4}, \mathrm{~T}_{5}$ groups and lower in $\mathrm{T}_{1}$ and $\mathrm{T}_{2}$ groups. However, the $\mathrm{EE}, \mathrm{Ca}$ and $\mathrm{P}$ contents were also numerically improved in the MPM included group, when compared to the control. The chemical composition of $60 \mathrm{~g}$ egg also followed the same trend as that of $100 \mathrm{~g}$ egg because the composition was proportionately converted.

The chemical composition of egg yolk was analysed separately from the eggs collected during the experiment and there was no significant difference in DM, OM, EE, TA, $\mathrm{Ca}$ and $\mathrm{P}$ but significantly higher values were observed in MPM added groups when compared to the control group $\left(\mathrm{T}_{1}\right)$. This indicated that the efficiency of utilization of protein for egg formation was better in MPM fed groups. The CP values of eggs reported in this study were lower than the CP values but higher fat, $\mathrm{Ca}$ and $\mathrm{P}$ values in the study conducted by (Ingrid et al., 2007) in chicken eggs. Rehman et al., (2011) reported almost similar CP values (6.3g) and fat values for chicken eggs of $60 \mathrm{~g}$ weight. Whereas Ahmad et al., (2017) fed Moringa olifera pod meal to Hyline W-36 layers and recorded higher values of $\mathrm{CP}, \mathrm{EE}$ for the egg yolk than the values reported in this study.

It can be concluded from the above results that higher level of MPM inclusion in the layer diets did not alter the egg quality parameters but maintained standard egg quality parameters. As the level of MPM increased in the commercial diet, xanthophyll content of the yolk and yolk colour increased accordingly than the control. But, the percentage of xanthophyll transferred from feed to yolk was highest in the control group (maize included diet) than MPM fed groups. The crude protein content of egg (without shell) and egg yolk was significantly higher in all MPM fed groups than the control. However, higher levels (4-6\%) of MPM did not affect the egg quality parameters but maintained standard egg quality on par with maize included diet. Therefore, it can be safely incorporated as unconventional feed resource by replacing some conventional feed ingredients like milling by-products without any adverse effect on egg quality parameters in commercial layers.

\section{References}

Ahmad, S., Khalique, A., Pasha, T. N. and Mehmood, S., 2017, Effect of Moringa olefera pods as feed additive on egg antioxidants, chemical composition and performance of commercial layers, S. Afr. J. Anim. 
Sci., 47(6): 864-873.

Altunta, G. and Aydin, G., 2014, Fatty acid composition of egg yolk from chickens fed a diet including marigold (Tagetes erecta L.). Journal of Lipids, p. 4.

AOAC, 2016, Official Methods of Analysis. Fifteenth edition. Association of Official Analytical Chemists, Washington, D.C.

Ariana, M., Abdolhossein, S., Mohammad, A. E., and Rahman, J., 2011, Effects of powder and extract form of green tea and marigold, and $\alpha$-tocopheryl acetate on performance, egg quality and egg yolk cholesterol levels of laying hens in late phase of production. J. Med. Plant. Res., 5(13): 2710-2716.

Hasin, B. M., Firdaus, A. J. M., Islam, M. A., UDDIN, M. J. AND ISLAM, M. S., 2006, Marigold and orange skin as egg yolk colour promoting agents. Int. J. Poult. Sci., 5(10): 979-987.

Ingrid, S. I., 2017, nutritional evaluation of egg compounds. Bioactive egg compounds. 117-144.

Moeini, M.M., Ghazi, S.H., Sadeghi, S., and Malekizadeh, M., 2012, The effect of red pepper (Capsicum annuum) and marigold flower (Tagetes erectus) powder on egg production, egg yolk color and some blood metabolites of laying hens; Iran. J. Appl. Anim. Sci., 3(2):301-305.

Olivera, M. C., Silva, W. D., Olivira, H. C. AND MOREIRA, E., 2017, Paprika and marigold extracts in diets for laying hens, Rev. bras. Saude prod. Anim., 18(2): 293-302.

Rehman, S. A., Akhter, S., Khan, S.H. and Ashraf. M. I., 2016, A comparative study on quality, proximate composition and cholesterol content of eggs and meat in Fayoumi and commercial white leghorn chickens. Cogent food and agriculture, 2:1195539.

Rezaei, M., Zakizadeh, S., and Eila, N., 2019, Effects of pigments extracted from the marigold flower on egg quality and oxidative stability of the egg yolk lipids in laying hens. Iran. J. Appl. Anim. Sci., 9(3): 541-547.

Rowghani, E., Maddahian, A. and ARB ABOUSADI, M., 2006, Effect of addition of marigold flower, safflower petals, red pepper on egg yolk colour and egg production in laying hens. Pak. J. Biol. Sci.,9(7): 1333-1337.

Sujatha, T., Jai sunder, Anandmoy K. and Madhu Sudan K., 2015, Production of pigment enriched desi chicken eggs by feeding of Tagetes petals. Adv. Anim. Vet. Sci., 3(3): 192-199.

\section{How to cite this article:}

Navya, V. G., B. Hemla Naik, T. Thirumalesh, D. Thippesh, B. U. Umesh, Y. Kanthraj and Jyothi M. Rathod. 2020. Influence of Marigold Petal Meal Rich in Xanthophyll as a Component of Commercial Layer Diets on Egg Quality Parameters. Int.J.Curr.Microbiol.App.Sci. 9(09): 2178-2185. doi: https://doi.org/10.20546/ijcmas.2020.909.273 